\title{
C-terminal hydrophobic region leads PRSV P3 protein to endoplasmic reticulum
}

\author{
Sarasate Eiamtanasate · Mila Juricek • \\ Yun-Kiam Yap
}

Published online: 1 August 2007

(C) Springer Science+Business Media, LLC 2007

Erratum to: Virus Genes (2007)

DOI 10.1007/s11262-007-0114-z

The publisher regrets an error was made in Table 1 of the original article. Below, please find the correct version of Table 1.

The online version of the original article can be found under doi:10.1007/s11262-007-0114-z.

S. Eiamtanasate · M. Juricek · Y.-K. Yap ( $₫)$

Institute of Molecular Biology and Genetics, Mahidol

University, Salaya Campus, 25/25 Phuttamonthon 4 Road,

Salaya, Phuttamonthon, Nakhon Pathom 73170, Thailand

e-mail: fryky@mahidol.ac.th

Present Address:

M. Juricek

Institute of Experimental Botany, Academy of Sciences

of the Czech Republic, Na Pernikáŕce 15, Prague 6160 00,

Czech Republic 


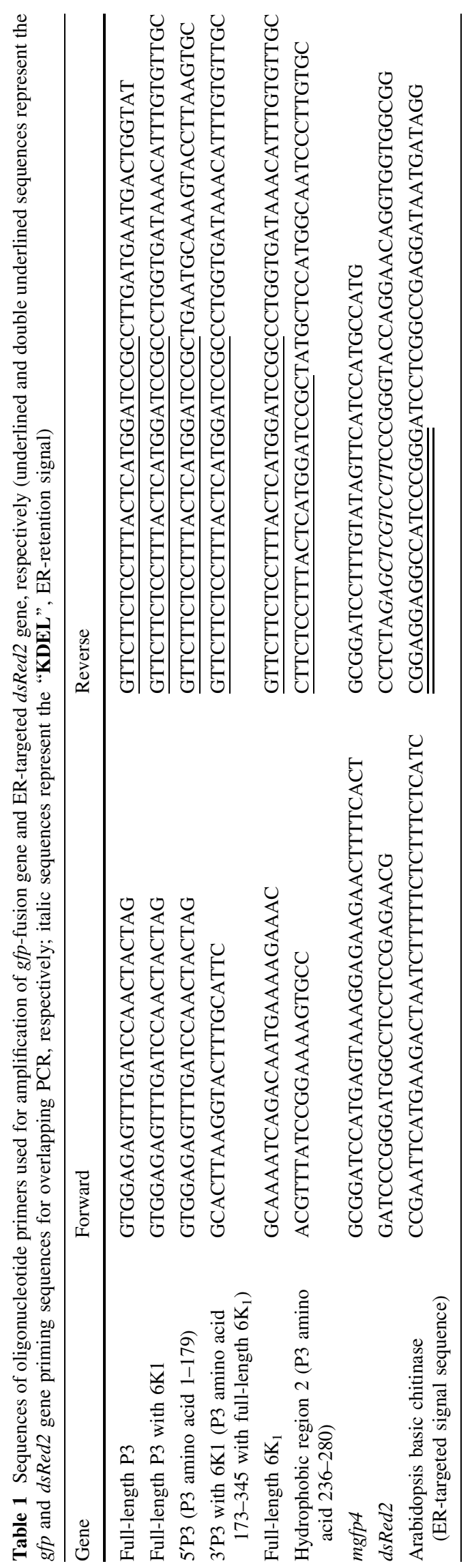

